\title{
Cultural attitudes to the Aged: AN INDIAN PERSPECTIVE
}

\begin{abstract}
Institutionalization of elderly Indians seems to have been increasing with the aging of the twentieth century. This paper looks at Indian thought and cultural practice with regard to the elderly in time perspective. Historically, although the main prescription to cultural practice and respect GOUNDEN P, PhD; PUCKREE T, PhD for the elderly came from the various Indian Scriptures, this was coloured by the specific needs of each society which changed when these societies were nomadic, settled farmers or were actively engaged in war. Later other factors like industrialization resulted in a breakdown of the extended family in which the father no matter how old or productive was the authority figure who demanded respect. This trend was also seen in published literature about the attitude of other nationalities towards their elderly. Health professionals have been grappling with the role of health care workers in achieving successful patients outcomes based on attitudes towards the elderly. More work needs to be done on this subject in this country.
\end{abstract}

\section{KEYWORDS: INDIAN CULTURE, ATTITUDES, ELDERLY}

$\mathrm{T}$ lechnological innovations have led to the information superhighway which has made the globe an electronic village. This globalization has resulted in a "one world" concept which allows for encounters with a diversity of cultures and cultural attitudes to life and living.

The progressive aging of our population as well as the fact that the baby, boom generation has reached the limits beyond middle age has meant that we are now on the era of a larger than ever population of elderly people around the world. First world countries have already focused on all aspects of aging including the cultural attitudes of different age groups of people towards aging as reflected in the plethora of literature on this topic. (Hunter et al,1979; CollettePratt,1976, Seccombe and Ishii-Kunz, 1991, Gonzalez et al,1997).

This paper explores cultural attitudes to aging with special reference to the Indian perspective. A South African Indian person can belong to any of a wide range of cultures which has been and is dependent on religious beliefs. Today's South African Indian may belong to a Christian, Islamic, Hindu (Gugerati, Hindi, Tamil or Telugu faiths), Buddhist or Sihk faith either by conversion or birth. Culture has been defined as the totality of tools, techniques, social institutions, attitudes, beliefs, motivations and systems of values which guide the way of life of the members of a group or society (Foster, 1973). An individual's cultural attitudes are shaped by human migration, war, religion, industrialization and urbanization but with an overriding foundation in the ancient scriptures be they, the bible, the Koran, the Vedic Thirukurral literature or the Pali texts of the Dhammapada of the Buddhist faith.

From $3000 \mathrm{BC}$ to $1750 \mathrm{BC}$ the Dravidians who were the main inhabitants of India, amongst others, worshipped the Lingam and the Yoni which were male and female fertility symbols respectively. Despite the fact that both the power of the mother and father figures of fertility were revered, the mother Goddess enjoyed precedence (Wheeler, 1966). The Lingam was and still is the universal symbol for Siva, the Godhead (Hopkins, 1971).

In the Dravidian world, the ancient Tamil devotional writings present the same level of unquestioning authority exercised by the heads of the family. An ancient Tamil devotional text presents the Dravidian view at that time. Translated the verse reads as follows: "One's father and mother take precedence even before God"' (Gaer, 1963).

The Aryans who invaded India through the Hindu Kush, a mountain pass in the Himalayas in around $1750 \mathrm{BC}$ settled in India became known as the Indo-Aryans
(Bouquet, 1996). These peoples were patriarchal and accorded a place of esteem to the father. These people subscribed to the ancient Aryan or Vedic literature like the Vedas, the Epics, the Ramayana and the Mahabharata, the Ghagavad Gita as well as the Puranas depending on the time in Indian religious history ( Stone,1976). The South Indians who are the Dravidians had their own scriptures for example the Thirrukurral.

The esteem afforded to the elderly in early Indo-Aryan and Dravidian culture was also linked to the role of the leader of the family depending on the type of life they led (Puckree, 1989). In the very early days when India was the focus of several invasions, the Indo-Aryans and the Dravidians lived nomadic lives which then progressed to settled farming communities.

In Nomadic communities the value of the male member of the household or

CORRESPONDENCE:

Prof P Gounden University of Durban-Westville Department of Physiotherapy

Private Bag X54001

Durban 4000

Tel: (031) 204-4817

Fax:(031) 204-4817

email: lpuckree@pixie.udw.ac.za 
community, as leader of the clan through adversity by wisdom and strength, could not be underrated. On the other hand in settled communities, where the extended family was large, it was the duty of the female head of the household to provide for her family. In both cases the older members of the family held positions of power which was retained until they were called to rest. The worship of ancestors throughout Indian history also confirms that early Indian thought showed a respect for the elderly members of ones family, clan or community.

In the pre-Vedic period c $1750 \mathrm{BC}$ to c $1300 \mathrm{BC}$ the father was the head of the household in a patriarchal society who lived in settled farming communities. The father had absolute authority over a joint family which consisted of a man, his wife, his children, his brothers and their children as well as his parents. However during the Vedic period 1300 $\mathrm{BC}$ to $800 \mathrm{BC}$ due to chronic warfare female infants and elderly people who were considered superfluous were exposed (Pinkham, 1967). The Vedic scriptures bear testimony to the lofty status enjoyed by the father. The ancient story of the lad Naciketas is a typical example of the esteem and respect in which the father and his pledged work were held. In the well known epic, the Ramayana, the son and heir to the throne, Rama, goes into voluntary exile in order to obey the promise made by his father in a moment of weakness (Dutt, 1898). From 800 to $600 \mathrm{BC}$ during the period of the Bramanas the male head of the household was in authority.

In all cases the North Indian vested full authority in father as the Head of the household in a patriarchal society.

The South Indian either placed authority in the father in the patriarchal clans viz. Kandhs and authority in the mother in matriarchal clan viz. the Santals and the Nairs amongst others (Hunter, 1892). Regardless of whether authority was given to the father or the mother, the family was an extended one in which great respect was afforded to the head of each household until his/her death.

Therefore in both North and South India reverence is accorded to and associated with the elderly. From the foregoing it follows that in old age when authority passes to the eldest son or whoever may be next in line, the retired head is still held in high esteem and not cast aside or neglected. The elderly continued to live as worthy and respected members of extended families.

This cultural thinking was carried with the Indian who was brought to South Africa as an indentured labourer beginning in 1860 to 1910 (Kuper, 1960). However, other factors shaped the Indian persons way of life. Industrialization meant that jobs could only be found at industries which led to the build up of urban societies. The movement away by younger members of the families in search of jobs and accommodation in urban areas led to a break down of the extended family into nuclear families. The roles of members within families were influenced by their productivity and the older generation became a burden to the younger ones. Colette-Pratt reported that a sample of college students devalued old age due to a loss of personal productivity, achievement and independence. Both young and middle aged people associated negative attitudes towards poor health and death with their devaluation of old age.

A significant number of people are living in "Dharmasalas" and old age homes or day care centres. It may be erroneous to dismiss the institutionalization of the elderly on the basis of the attitudes of Indians only. Anecdotal evidence shows that selected elderly people in Durban prefer to live in residential facilities because of the high crime rate in which some of them are the prime targets. In many cases the elderly are left alone at home when the younger members of the family are gone to work.

The Americans who are both ageic and age phobic have developed attitudes towards older persons that prevent them from access to comprehensive health care. Fishman explored the attitudes of physicians, nurses and dentists which may have resulted in the above feelings towards the elderly (Fishmann, 1989). Health professionals are expected to practice their profession on patients from a diversity of cultures. South Africa, is also a virtual boiling pot of cultures just like that in America. It is important for health care professionals who themselves come from diverse cultures, religious beliefs and thoughts that focus on creation or evolution to appreciate the gaps that exist between generations about cultural attitudes and practices. The impact of urbanization, industrialization, liberation, family structures etc. on the life of the aging and aged person must be understood. Without a survey of actual attitudes and practices one can only speculate on current practices with regard to the South African elderly.

Even in today's world, with the existence of nuclear families, child care is still a burden of the elderly who often are caring for grandchildren, great grand children and even great great grand children. The saying that "as we grow older we move more towards childhood" makes this task of the elderly taking care of the younger ones a worthwhile task with the respect afforded to the elderly. This practice is consistent with the empirical data by Thomas and Yamamoto 1975 which shows that school aged children do not share the general negative attitude towards old age (Thomas and Yamamoto, 1975). As shown by Gonsalez et al (1997) the most important influence on attitude is the individual experience each person has shared with the elderly.

Since the South African health professionals' basic religious values may have been coloured by a variety of extrinsic factors it may be difficult to predict attitudes without a controlled survey. It is documented however that the South African has retained the basic teachings from the holy scriptures but has also borrowed certain western practices that allow him/her to live successfully in a foreign land. However the number of residential facilities for the aged speaks of the changes in practices. Whether the aged live in residential facilities or in modified extended families their health care needs have to be individualized. Health care professionals must be taught the impact of attitudes and communication on the success of interventions and an aim to return the individual to some degree of independent life.

A review of the literature shows that the status of the elderly has not been greatly affected by culture. Although no literature exists on the important aspect 
of the effects of urbanization and industrialization on the role of the aged person in society, a correlation seems to exist between the two.

\section{REFERENCES:}

1. Bouquet AC 1969 Hinduism. Hutchinson Co. Ltd, London

2. Collette-Pratt C 1976 Attitudinal Predictors of devaluation of old age in a multigenerational sample. J Gerontol. 31: 193-7

3. Dutt RC 1898 The Mahabharata, the Epic of ancient India. Condensed into English verse, London

4. Fishman SK 1989 Health professionals' attitudes toward older people. Dent. Clin. North Am. 33: 7-10

5. Foster GM 1973 Traditional societies and technological change. Harper and Row Publishers, New York
6. Gaer J 1963 What the great religions believe? Dodd mead and Co., New York

7. Gonsalez PJL, Rodriguez VC, Salazar CJM, Sobrino FR 1997 (What do the young think about the old?) Enferm 20: 66-9

8. Hopkins TJ 1971 The Hindu religious tradition. Dickenson Publishing company, Inc., California

9. Hunter K, Kinn MW, Pratt TC 1979 Minority women's attitudes about aging. Exp. Aging Res. 5: 95-108

10. Hunter WW 1892 The Indian Empire. Smith, Elder and company, London

11. Kuper H 1960 Indian people in Natal. University Press, Durban

12. Mahadevan TMP 1960 Outlines of Hinduism. Chetana Publishers, Bombay

13. Pinkam MW 1967 Women in the sacred scriptures of Hinduism. AMS Press Inc., New York

14. Puckree T 1989 The evolvement in the role, status and education of the female in
India and of the South African Indian female up to 1985 , master of education thesis. Unisa

15. Puckree R, Chetty TP, Ramlakan S, Simelane TVS, Lin J 1997 An evaluation of the functional status of a geriatric residential facility in South Africa. Disability and Rehabilitation 19: 552-5

16. Seccombe KM, Ishii-Kuntz 1991 Perceptions of problems associated with aging: comparisons among four older age cohorts. Gerontologisı 31: 527-33

17. Stone M 1976 When God was a woman. A Harvest/HBJ Book, Harcourt Brace, New York

18. Thomas EC, Yamamoto K 1975 Attitudes towards age: an exploration in school-age children. Int. J Aging Hum. Dev. 6:117-29

19. Vedalankar PN, Shastra navanitam 1981 A concise study of Hindu scriptures, Veda Niketan, Durban

20. Wheeler M 1966 Civilization of the Indus Valley and beyond. Thomas and Hudson, London

\section{The South African Medical Arts Society WILL BE HOLDING ITS

YOU ARE CORDIALLY INVITED TO ATTEND THE OFFICIAL OPENING TO Be held ON MONDAy EVEning the 23Rd August 1999 at 18:00hrs FOLLOWED BY A FINGER SUPPER.

ThIS WILl be Held AT THE IMPRESSIVE PREMICES OF THE PHARMACEUTICAL Society of South Africa in Glenhove Rd, Houghton, Johannesburg. ROCHE PRODUCTS WHO HAVE A LONG HISTORY OF INTEREST IN THE ARTS SPONSOR THE ANNUAL EVENT.

Exponents of paint, clay, bronze and terracotta are invited to join the society and exhibit two items in any of the above media. All paintings must be framed and be ready to be hung and should be handed in on Saturday 21 August between 09:00 and 12:00 noon.

FOR FURTHER INFORMATION PLEASE PHONE:

Rina Emslie at Roche Products - Tel no: (011) 974-5335 or Charmaine Levy - Tel no: (011) 486-3487 